\title{
CAMPYLOBACTER JEJUNI IN SLAUGHTERED CHICKENS FROM THE VIEWPOINT OF FOOD HYGIENE
}

\author{
Norika MAŤAŠOvSKÁ, Olga SLADKÁ, O. MRÃZ, Z. MATYÁS and Iva TOMANCOVÁ
}

Institute of National Public Health, Prague

Centre of Food Chain Hygiene, 61242 Brno

Received fuly 7, 1991

\begin{abstract}
Matašovská Norika, Olga Sladká, O. Mráz, Z. Matyáš and Iva Toman cová: Campylobacter jejuni in Slaughtered Chickens from the Viewpoint of Food Hygiene. Acta vet. Brno, 61, 1992: 61-67.

A total of 440 slaughtered chickens coming from 27 farms were examined for presence of Campylobacter jejuni between 1st Feb. 1990 and 31st Jan. 1991. The relevant specimens were taken from the outer and inner carcass surfaces, ileum contents, liver parenchyma and bile from groups of 10 birds each week. Isolation attempts yielded 366 C. jejuni strains. Of the 38 and $47(10.3 \%$ and $12.8 \%)$ were isolated from the outer and inner carcass surfaces, respectively, 121 (35\%) from ileum contents, $92(25 \%)$ from liver parenchyma and $68(18.6 \%)$ from bile.

The proportions of contaminated chicken carcasses showed two peaks, reaching $62.5 \%$ and $62 \%$ in May and October, respectively. An almost parallel trend vas recorded for the isolations from ileum contents and liver parenchyma where the highest number of strains ( $45 \%$ and $30 \%$ respectively) coincided with the May peak, whereas the highest proportions of isolations from bile $(30 \%)$ coincided rather with the second peak. The proportions of $C$. jejuni isolated from the outer and inner carcass surfaces were relatively low, averaging $9.4 \%$ and $11.4 \%$ respectively, and did not show much fluctuation. The proportions of C. jejuni isolated from bile averaged $13.8 \%$.

In $82(22.4 \%)$ C. jejuni strains solitary colonies were observed also after control aerobic incubation at $42{ }^{\circ} \mathrm{C}$, but attempts at their further passage under these conditions yielded negative results.

C. jejuni carriers and shedders as well as the incidence of asymptomatic C. jejuni infection among chickens do not urge either the farmer or the veterinarian to take any measures, but the consumption of $C$. jejuni- infected chicken meat constitutes a major health hazard for man.
\end{abstract}

Campylobacter jejuni, slaughtered chickens, food hygiene

Campylobacter jejuni was first described as Vibrio jejuni (Jones et al. 1931) and is also known under the names of Vibrio hepaticus (Mathey and Rissberger 1964) or Campylobacter fetus subsp. jejuni (Smibert 1974). It is a causative agent of abortion in sheep, diarrhoea in calves and lambs, campylobacter hepatitis in chickens and febrile enteritis in man.

A point of particular epidemiological importance is the fact that $C$. jejuni can also be iso'ated from the intestinal tract of clinically healthy cattle, sheep, goats, pigs, rabbits, domestic fowls, turkeys, ducks, pigeons, dogs, cats, monkeys, sparrows, blackbirds and starlings (S mibert 1984). From the intestinal tract it can make its way to the liver and, upon evisceration, also to the outer and inner surfaces of farm animal carcasses. In the domestic fowl this possibility has been demonstrated:

(1) on the outer surface after scalding and plucking (Baker et al. 1987) in $20 \%$ of the carcasses;

(2) on the inner surface after evisceration (Pěgřimková 1986, Marinescu et al. 1987; Míčková 1987) in $28.7 \%$ to $92 \%$ of the carcasses;

(3) in the liver (Khalafalla 1990) in $40 \%$ of the carcasses.

Examination of the bile has yielded negative results (Oo sterom et al. 1983). 
Further fate of these bacteria depend on the mode of carcass processing and on culinary processing of chicken meat.

Campylobacteriosis of this aetiology in man was demonstrated in Europe (Belgium, England, Holland, Sweden), Africa (Zaire, South Africa) and Australia in the seventies. In our country it has been described by Tesařová and Kubecová (1982), Kahlich et al. (1983) and Kováčová (1986), but in all these cases direct isolation of $C$. jejuni from the incriminated food is lacking. According to Oosterom (1985) the main cause of the disease is the consumption of chicken meat or chicken meat products.

Clinical signs of the disease are observed after a 3- to 5-day incubation period. They include pyrexia, headache, back-pain and muscle ache, soon followed by pain in the abdominal region and diarrhoea. The stools are thin to liquid and occasionally bile or blood-tinged. The diarrhoea generally subsides after 2 to 3 days and the disease as a whole lasts 1 to 2 weeks. Non-medicated patients shed the bacteria for as many as 5 weeks (Butzler and Skirrow 1979).

The present study was designed to obtain information on $C$. jejuni occurrence in flocks of domestic fowls and on C. jejuni contamination of chicken meat and giblets in our country.

\section{Materials and Methods}

A total of 440 chickens coming from 27 farms were examined for the presence of $C$. jejuni between 1st Feb. 1990 and 31 Jan. 1991. The tissue specimens were taken from the (1) outer surface of plucked chicken carcasses, (2) inner surface of eviscerated carcasses, (3) ileum contents, (4) liver parenchyma and (5) bile in a poultry slaughter-house from groups of 10 birds each week. Five farms were represented on 2 occasions, two farms on 3 occasions and one farm on 9 occasions. The origin of each group of 10 birds was recorded.

Swabs taken from wet outer and inner carcass surfaces, ileum contents and liver parenchyma as well as 2 to 3 drops of bile obtained with a syringe were each placed into test tubes containing circa $7 \mathrm{ml}$ transport medium (thioglycolate medium IMUNA) completed with $1 \%$ liquid supplement " $C$ " enriched with antibiotics (cephalotin, vankomycin) and trimethoprim. After 24-h incubation at $42^{\circ} \mathrm{C}$ inoculations were made into blood agar prepared from IMUNA base No. 4, $7 \%$ defibrinated horse blood and $1 \%$ supplement " $\mathrm{C}$ ". Incutation was carried out under microaerophilic conditions at $42{ }^{\circ} \mathrm{C}$ for $48 \mathrm{~h}$ in a modified apparatus according to Hussels as cited by Hallman (1955).

From suspect colonies (generally showing a tendency to creeping growth) pure cultures were started on the blood agar as described above except that supplement " $C$ " was replaced with its $1 \%$ non-antibiotic version " $A$ ". The two supplements were obtained from the Department of Medical Microbiology, Medical Faculty Hospital, Motol, Prague 5.

The nutrient base used for testing for nitrate reduction, indole production, hydrogen sulphide production, glucose oxidation and growth in $1 \%$ glycine contained $2.5 \mathrm{~g}$ tryptose peptone, $0.75 \mathrm{~g}$ beef extract, $1.25 \mathrm{~g} \mathrm{NaCl}, 0.25 \mathrm{~g} \mathrm{Na} \mathrm{HPO}$ and $250 \mathrm{ml}$ distilled water. After addition of the test substrates, dispensing, steriziliation and inoculation we carried out incubation under microaerophilic conditions at $42{ }^{\circ} \mathrm{C}$.

The isolated strains were identified according to the latest edition of Bergey's Manual (Krieg and Holt 1984) and in the light of the published data on newly accepted campylobacters (Benjamin et al. 1983; Gebhart et al. 1985; McClung et al. 1983; Neil et al. 1985; Roop et al. 1985; Steele and Owen 1988; Tanner et al. 1981 and Totten et al. 1985). See Table 1.

\section{Results}

A total of 366 strains of $C$. jejuni were isolated from 440 chicken carcasses during 12 months. Of these 38 and 47 , were isolated from the outer and inner carcass surfaces, respectively, 121 from the ileum contents, 92 from the liver parenchyma and 68 from bile.

The positive results varied from week to week and from farm to farm, ranging from 0 to $100 \%$ (with an average of $50 \%$ ) without any clear trend. Nevertheless, it is of interest to note that out of 44 batches of 10 chickens $3(6.8 \%)$ batches were without $C$. jejuni findings but only one farm proved to be uninfected.

From the frequency of $C$. jejuni findings in the individual weeks and organs it appears that the mean contamination of the farms amounted to $50 \%$, while 
Table 1

Differentiation of campylobacters

\begin{tabular}{|c|c|c|c|c|c|c|c|c|}
\hline 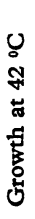 & 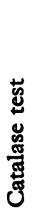 & 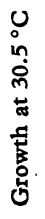 & 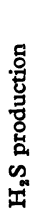 & 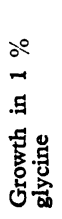 & 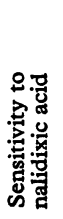 & 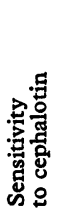 & Species or subspecies: & 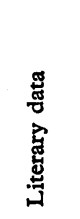 \\
\hline+ & + & + & + & + & + & - & \multirow{7}{*}{$\begin{array}{l}\text { C. Coli } \\
\text { C. hyointestinalis } \\
\text { C. laridis } \\
\text { C. jejuni } \\
\text { C. mucosalis } \\
\text { C. sputorum subsp. sputorum } \\
\text { C. cinaedi } \\
\text { C. concisus } \\
\text { C. cryaerophila } \\
\text { C. fennelliae } \\
\text { C. fetus subsp. fetus } \\
\text { C. fetus subsp. venerealis } \\
\text { C. jejuni subsp. doylei } \\
\text { C. nitrofigilis } \\
\text { C. sputorum subsp. bubulus }\end{array}$} & \multirow{6}{*}{$\begin{array}{l}5,27 \\
9 \\
2 \\
11,20 \\
16,28 \\
36\end{array}$} \\
\hline+ & + & + & + & + & - & + & & \\
\hline+ & + & + & + & + & - & - & & \\
\hline+ & + & - & + & + & + & - & & \\
\hline+ & - & $\cdot$ & + & - & d & + & & \\
\hline+ & - & + & + & + & - & + & & \\
\hline $\begin{array}{l}\overline{-} \\
\bar{z} \\
\overline{-} \\
\bar{z} \\
\overline{-}\end{array}$ & $\begin{array}{l}+ \\
+ \\
+ \\
+ \\
+ \\
\dot{+} \\
-\end{array}$ & $\begin{array}{l}\dot{ } \\
\dot{+} \\
\dot{+} \\
\dot{+} \\
\dot{d} \\
\dot{.}\end{array}$ & $\begin{array}{l}\overline{+} \\
\overline{-} \\
\bar{d} \\
d \\
\bar{d} \\
\bar{t}\end{array}$ & $\begin{array}{l} \pm \\
\pm \\
\pm \\
\pm \\
\dot{+} \\
\dot{+}\end{array}$ & $\begin{array}{l}+ \\
+ \\
+ \\
\pm \\
- \\
\dot{+} \\
\mathrm{d}\end{array}$ & $\begin{array}{l}+ \\
\dot{+} \\
+ \\
+ \\
+ \\
+ \\
+ \\
+\end{array}$ & & $\begin{array}{l}35 \\
33 \\
23 \\
35 \\
8,33 \\
8 \\
32 \\
18 \\
17,29\end{array}$ \\
\hline
\end{tabular}

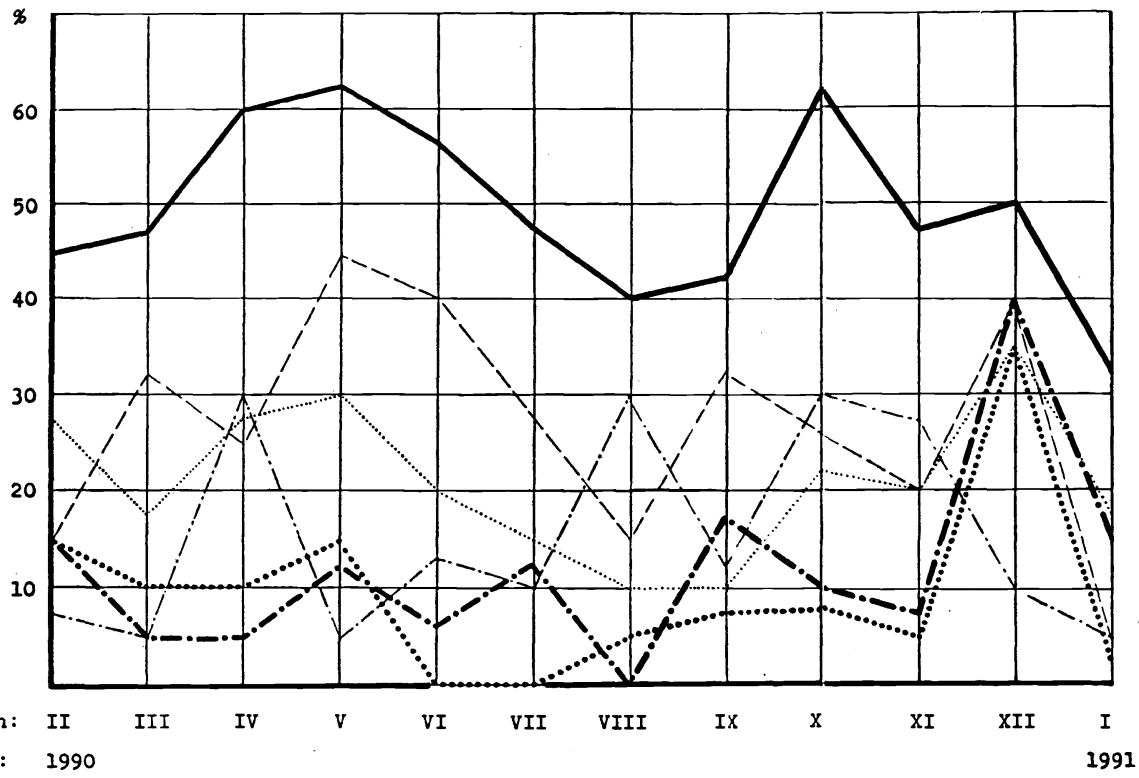

Explanations :

= outer surface = liver

-.-.- = inner surface

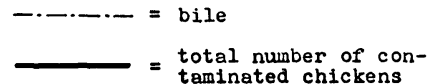

Fig. 1: Frequency of $C$. jejuni in slaughtered chickens during the year 
the mean contamination demonstrated from the outer carcass surface, inner carcass surface, ileum contents, liver parenchyma and bile was $9.4 \%, 11.4 \%$, $27.7 \%, 21 \%$ and $13.8 \%$, respectively. The results obtained during the whole year are presented graphically in Fig. 1. It can be seen that the curve representing total percentages of contaminated chickens had two peaks, one in May and the other in October, during which months the proportions of $C$. jejuni - contaminated chickens reached $62.5 \%$ and $62 \%$, respectively. The first peak coincided with the highest percentages of $C$. jejuni contamination demonsrtated in the ileum and liver (45\% and $30 \%$ ) and the second peak coincided more or less with the highest proportion of $C$. jejuni contamination demonstrated in bile $(30 \%)$. The findings of $C$. jejuni from the outer and inner carcass surfaces were relatively low, ranging from 0 to $17.5 \%$, and showed little fluctuation during the year except in December when the number of chickens was only half that examined in previous months and the contamination was generally demonstrated in the same birds and organs.

In $82(22.4 \%) C$. jejuni strains solitary colonies were observed also after control aerobic incubation at $42{ }^{\circ} \mathrm{C}$, but attempts at their further passage under these conditions yielded negative results. They were recorded occasionally throughout the year: 9 times $(11 \%)$ from the outer surface, 10 times $(12.2 \%)$ from the inner surface, 30 times $(36.5 \%)$ from the ileum contents, 16 times $(19.5 \%)$ from the liver parenchyma and 17 times $(20.7 \%$ ) from bile.

\section{Discussion}

The information on $C$. jejuni published to date is extensive and a certain gap in the relevant literature regarding the investigations carried out in chickens became apparent. Essentially the same can be said about the characteristics used for the differentiation of campylobacters (see Tablel) where vacancies appear mainly in the column "Growth at $30.5^{\circ} \mathrm{C}$ ".

The cultivation on the nutrient media used in our study and the evaluation of the results presented no difficulties thanks, among other things, to parallel inoculations of C. jejuni CCM 6207 type strain. The findings of solitary colonies growing also under aerobic conditions were due to the fact that we included this control incubation of the isolated strains. Their frequency with respect to the individual organs was more or less equal, amounting to $22.4 \pm 5 \%$. It is of interest to note that similar observations were made in the strains of Campylohacter cryaerophila the subcultures of which were reported to grow under both aerobic and anaerobic conditions (Neil et al. 1985).

The seasonality in the occurrence of $C$. jejuni strains in our study became apparent particularly in the total percentages of contaminated chicken carcasses peaking in May and October. A similar observation was reported by Doyle (1984) in his study based on the investigation of faeces from laying hens.

The mean proportions of contaminated chickens in our study were twice to 2.5 times lower than those reported by Baker et al. (1987) and Míčková (1987) and the mean proportion of positive findings in the liver parenchyma was half that recorded by Khalafalla (1990). The reasons of these differences are difficult to discuss because they reflect both the epizootiological situation in the flocks and some poultry slaughter-house practices such as temperature of scalding water and general sanitation standard.

For assessing the bactericidal effect of heat treatment of poultry meat products 
it would have been of interest to examine the sensitivity of $C$. jejuni to temperatures used in this operation but these questions have been thoroughly considered by other investigators (Doyle and Roman 1981; Blankenship and Graven 1982; Matyáš and Tomancová 1985).

\section{Campylobacter jejuni u jatečných kư̌at z pohledu hygieny potravin}

Během 12 měsíců bylo od 1.2.1990 do 31.1. 1991 vyšetřeno 440 jatečných kuřat na nosičství $C$. jejuni. Každotýdenní šarže 10 kuřat pocházela $\mathrm{z}$ některé ze 27 drůbežích farem a prríslušné vzorky byly odebrány $z$ vnějšího a vnitřního povrchu trupu, obsahu ilea, $z$ hloubky jater a ze žluče.

Dosažené výsledky:

1. Z jednotlivých vzorků bylo izolováno celkem 366 kmenů $C$. jejuni, a to 38 a $47(10,3$ a 12,8 \%) z vnějšího a vnitřního povrchu trupu, $121(35 \%)$ z obsahu ilea, $92(25 \%)$ z jaterního parenchymu a $68(18,6 \%)$ ze žluče.

2. Prưběžné počty kontaminovaných kuřat představovaly dvouvrcholovou křivku s maximy v měsících květnu a říjnu, kdy frekvence nálezů dosáhla 62,5 , resp. $62 \%$.

3. Téměř paralelní trend byl pozorován také u $C$. jejuni $\mathrm{v}$ obsahu ilea (max. $=$ $=45 \%$ ) a v jaternim parenchymu (max. $=30 \%$ ), zatímco v souvislosti s druhým vrcholem to bylo spiše ve žluči (max. $=30 \%$ ).

4. Záchyt $C$. jejuni na vnějším i vnitřním povrchu byl relativně řídký (s průměry 9,4 a $11,4 \%$ ) a dosti vyrovnaný. Jeho prủměrný záchyt ve žluči činil $13,8 \%$.

5. U $82(22,4 \%)$ kmenů $C$. jejuni se objevily ojedinělé kolonie i v kontrolní aerobní pasáži při $42^{\circ} \mathrm{C}$, ale jejich další přeočkování za těchto podmínek vyznělo negativně.

Nosičství a vylučovatelství $C$. jejuni, stejně jako bezsymptomní průběh infekce u kuřat nenutí chovatele ani veterinárního lékaře $\mathrm{k}$ žádným zásahưm, ale pro člověka-konzumenta znamená taková drůbež vážné zdravotní nebezpečí.

\section{Campylobacter jejuni боенских цыплят с точки зрения гигиены пищевых продүктов}

В течение 12 месяцев - с 1-го февраля 1990 г. по 31-ое января 1991 года - исследовали 440 боенских цыплят, чтобы определить носительство C. јејuni. Еженедельная партия 10 цыплят происходила из одной из 27 птицеферм и соответствующие образцы получали с наружной и внутренней поверхности тела, содержания подвздошной кишки, из глубинных слоев печени и желчи. Полученные результаты:

1. Из отдельных образцов изолировали в итоге 366 штаммов C. јеjuni, а именно 38 и $47(10,3$ и 12,8 \%) из наружной и внутренней поверхности тела, 121 (35\%) из содержания подвздошной кишки, 92 $(25 \%)$ - из паренхимы печени и $68(18,6 \%)$ из желчи.

2. Систематически проводимые подсчеты численности контаминированных цыплят представляли собой двухпиковую кривую с максимумом в мае и октябре, когда их частота достигла 62,5 или $62 \%$.

3. Почти параллельная тенденция наблюдалась также у C. јејuni в содержании подвздошной кишки (максимально $45 \%$ ) и в паренхиме 
печени (максимально $30 \%$ ) между тем как в связи со вторым пиком максимум сводилось скорее к желчи (30\%).

4. Выявление $C$. јејuni на наружной и внутренней поверхности тела встречалось сравнительно редко (в среднем 9,4 и $11,4 \%$ ) и отличалось уравновешенностью. Среднее наличие в желчи достигало 13,8\%.

5. У $82(22,4)$ штаммов $C$. јејuпi появились отдельные колонии также в контрольном аэробном пассаже при $42{ }^{\circ} \mathrm{C}$, однако их повторная прививка в данных условиях была негативной.

Носительство и выделение $C$. јејипi а также бессимптомный ход инфекции у цыплят не заставляет птицеводов ни ветврачей прибегать к вмюшательствам, однако для потребителя такие птииы представляют серьезную угрозу здоровью.

\section{References}

BAKER, R. C.-PARADES, M. D. C.-QURESHI, R. A.: Prevalence of Campylobacter jejuni in eggs and poultry meat in New York state. Poultry Sci., 66, 1987: 1766-1770

BENJAMIN, J.-LEAPER, S.-OWEN, R. J. et al.: Description of Campylobacter laridis, a new species comprising the nalidixic acid resistant thermophilic Campylobacter (NARTC) group. Curr. Microbiol., 8, 1983: 231-238

BLANKENSHIP, L. C.-GRAVEN, S. E.: Campylobacter jejuni survival in chicken meat as a function of temperature. Appl. Environ. Microbiol., 44, 1982: 88-92

BUTZLER, J. P.-SKIRROW, M. B.: Campylobacter enteritis. Clinics in Gastrology, 8, 1979: 737-765

DOYLE, L. P.: The etiology of swine dysentery. Am. J. Vet. Res. , 9, 1948: 50-51

DOYLE, M. P.: Association of Campylobacter jejuni with laying hens and eggs. Appl. Environ. Microbiol., 47, 1984: 533-536

DOYLE, M. P.-ROMAN, D. J.: Prevalence and survival of Campylobacter fetus subsp. jejuni as a function of temperature and pH. J. Food Protect., 44, 1981: 596-601

FLORENT, A.: Les deux vibrioses génitales de la bête bovine: La vibriose venerienne, due a Vibrio foetus venerealis, et la vibriose d'origine intestinale, due a V. foetus intestinalis. Proc. 10th Int. Vet. Cong. Madrid 2, 1959: 953-957

GEBHART, C. J.-EDMONDS, P.-WARD, G. E. et al.: "Campylobacter hyointestinalis" sp. nov.: a new species of Campylobacter found in the intestines of pigs and other animals. J. Clin. Microbiol., 21, 1985: 715-720

HALLMANN, L.: Bakteriologie und Serologie. II. Aufl., G. Thieme, Stuttgart 1955, 850 p.

JONES, F. S.-ORCUTT, M.-LITTLE, R. B.: Vibrios (Vibrio jejuni n. sp.) associated with intestinal disorders of cows and calves. J. Exp. Med., 53, 1931: 853-864

KAHLICH, R. - PALEČEK, A. - KOTLÁR, V. et al.: První pohled na kampylobakteriózu u nás. Bull. Cs. spol. mikrobiol., 24, 1983: 19-21

KHALAFALLA, F. A.: Campylobacter jejumi in poultry giblets. J. Vet. Med. B, 37, 1990: $31-34$

KOVÁCOVÁ, D.: Naše zkušenosti s epidemiologií nákaz vyvolaných Campylobacter jejuni. Csl. epidem., mikrobiol. a imunol., 35, 1986: 15-23

KRIEG, R.-HOLT, J. G. (edit.): Bergey's Manual of Systematic Bacteriology. Vol. 1. Williams and Wilkins, Baltimore-London 1984. Pp. 964

LAWSON, G. H. K.-LEAVER, J. L.-PETTIGREW, G. W. et al.: Some features of Campylobacter sputorum subsp. mucosalis subsp. nov., nom. rev. and their taxonomic significance. Int. J. Syst. Bact., 31, 1981: 385-391

LOESCHE, W. J.-GIBBONS, R. J.-SOCRANSKY, S. S.: Biochemical characteristics of Vibrio sputorum and relationship to Vibrio bubulus and Vibrio fetus. J. Bacteriol., 89, 1965: 1109 to 1116

McCLUNG C. R.-PATRIQUIN D. G.-DAVIS, R. E.: Campylobacter nitrofigilis sp. nov., a nitrogen-fixing bacterium associated with roots of Spartina alterniflora Loisel. Int. J. Syst. Bact., 33, 1983: 605-612

MARINESCU, M.-FESTY, B.-DERIMAY, R. et al.: High frequency of isolation of Campylobacter coli from poultry meat in France. Eur. J. Clin. Microbiol., 6, 1987: 693-695

MATHEY, W. J.-RISSBERGER, A. C.: A turkey sinus vibrio (Vibrio meleagridis n. sp.) compared with the avian hepatitis vibrio (Vibrio hepaticus, n. sp.). Poultry Sci., 43, 1964: 1339 
MATYÁS̆, Z.-TOMANCOVÁ, I.: Problematika Campylobacter jejuni $v$ hygieně potravin. Veterináŕství, 35, 1985: 536-538

MÍCKKOVÁ, V.: Campylobacter jejuni u jatečně opracované drůbeže. Vet. med. (Praha), 32, 1987: 557-562

NEIL, S. D.-CAMPBELL, J. N. - O'BRIEN, J. J. et al.: Taxonomic position of Campylobacter cryaerophila sp. nov. Int. J. Syst. Bact., 35, 1985: 342-356

OOSTEROM, J.: Studies on the epidemiology of Campylobacter jejuni. Med. diss., Univ. Utrecht 1985.

OOSTEROM, J.-NOTERMANS, S.-KARMAN, H. et al.: Origin and prevalence of Campylobacter jejuni in poultry processing. J. Food Protect., 46, 1983: 339-344

PĚGRIMKOVÁ, J.: Campylobacter jejuni a možné cesty jeho šírení v potravinách. In: Vzájemný vztah mikroorganismů a potravin, a metody sledování. CSAV Praha, 1986: 25-29

PRÉVOT, A. R.: Manuel de classification et de détermination des bactéries anaérobies. II. edit. Masson et Comp., Paris 1948. 290 p.

ROOP, R. M.-SMIBERT, R. M.-JOHNSON, J. L. et al.: Campylobacter mucosalis (Lawson, Leaver, Pettigrew et al.) comb. nov.: Emended description. Int. J. Syst. Bact., 35, 1985: 189 to 192

SEBALD, M. - VÉRON, M.: Teneur en bases de l'ADN et classification des vibrions. Ann. Inst. Pasteur (Paris), 105, 1963: 897-910

SMIBERT, R.: Campylobacter. In: Buchanan and Gibbons (edit): Bergey's Manual of Determinative Bacteriology. VIII. edit. Williams and Wilkins, Baltimore 1974. 1246 p.

SMIBERT, R. M.: Genus Campylobacter Sebald and Véron 1963. In: Krieg R., Holt J. G.(edit.): Bergey's Manual of Systematic Bacteriology. Vol. 1. Williams and Wilkins, Baltimore-London 1984, $964 \mathrm{p}$.

STEELE, T. W.-OWEN, R. J.: Campylobacter jejuni subsp. doylei subsp. nov., a subspecies of nitrate-negative Campylobacter isolated from human clinical specimens. Int. J. Syst. Bact., 38, 1988: 316-318

TANNER, A. C. R. - BADGER, S. - LAI, C. -H. et al.: Wolinella gen. nov. Wolinella succinogenes (Vibrio succiogenes Wolin et al.) comb. nov., and description of Bacteroides gracilis sp. nov., Wolinella recta sp. nov., Campylobacter concisus sp. nov., and Eikenella corrodens from humans with periodontal disease.. Int. J. Syst. Bact., 31, 1981: 432-445

TESAŘOVÁ, J.-KUBECOVÁ, D.: Kampylobakterová infekce. Prakt. lékař, 62, 1982: 390-394

TOTTEN, P.-FENNELL, C. L.-TENOVER, F. C. et al.: Campylobacter cinaedi (sp. nov.) and Campylobacter fennelliae (sp. nov.): two new Campylobacter species associated with enteric disease in homosexual men. J. Inf. Dis., 151 1985: 131-139

VÉRON, M.-CHATELAIN, R.: Taxonomic study of the genus Campylobacter Sebald and Véron and designation of the neotype strain for the type species, Campylobacter fetus (Smith and Taylor) Sebald and Véron. Int. J. Syst. Bact. , 23, 1973: 122-134 